\title{
Scrotal Carcinoma
}

National Cancer Institute

\section{Source}

National Cancer Institute. Scrotal Carcinoma. NCI Thesaurus. Code C6389.

A carcinoma occurring in the scrotum. 